\title{
Literature in EFL classes: four teachers' experiences in Brazil
}

\author{
Anna Carolyna Ribeiro Cardoso* \\ Neuda Alves do Lago**
}

\begin{abstract}
Some of the benefits of using literature in EFL classes include improving vocabulary, critical thinking and providing authentic material. Researchers such as Melo Júnior (2015) and Lago (2016; 2017) investigate literature in EFL contexts, noticing how literature can also motivate students. This paper aims to analyze English teachers' experience in Goiás, Brazil, and their relationship with literature in their EFL classes. Its purpose is to investigate whether these teachers use literary works during their lessons. Four teachers were interviewed for this case study. The results show these teachers attribute importance to literature in EFL contexts.
\end{abstract}

Keywords: English literature. EFL. Teachers. Classroom.

Resumo: Alguns dos benefícios do uso da literatura nas aulas de EFL são a melhora do vocabulário, promover o pensamento crítico e fornecer material autêntico. Pesquisadores como Melo Júnior (2015) e Lago (2016; 2017) investigam a literatura em contextos de EFL e como esta também pode motivar estudantes. Este artigo tem como objetivo analisar as experiências de professores de inglês em Goiás e sua relação com a literatura em aulas de inglês. Analisa se esses professores consideram a literatura importante e se a utilizam em suas aulas. Quatro professores foram entrevistados sob a perspectiva de um estudo de caso. Os resultados comprovam que esses professores atribuem importância à literatura.

Palavras-chave: Literatura inglesa. EFL. Professores. Sala de aula.

Resumen: Algunos de los beneficios de usar literatura en las clases de EFL son mejorar el vocabulario, promover el pensamiento crítico y proporcionar material auténtico. Investigadores como Melo Júnior (2015) y Lago (2016; 2017) investigan la literatura en contextos EFL y cómo ella también puede motivar a los estudiantes. Este texto tiene como objetivo analizar las experiencias de los profesores de inglés en Goiás, Brasil y su relación con la literatura en clases de inglés. Analiza si estos profesores consideran importante la literatura y si la usan durante las clases. Cuatro docentes fueron entrevistados en la perspectiva del estudio de caso. Los resultados prueban que los profesores dan importancia a la literatura.

Palabras clave: Literatura inglesa. EFL. Profesores. Clases.

\footnotetext{
* Doutoranda em Estudos Linguísticos pela Universidade Federal de Goiás (UFG). http://orcid.org/ooooo002-6465-6485 / E-mail: karolrc26@gmail.com

${ }^{* *}$ Professora do departamento de Língua Inglesa da Faculdade de Letras da Universidade Federal de Goiás (UFG). http://orcid.org/oooo-0003-0887-9083 / E-mail: neudalago@ufg.br
}

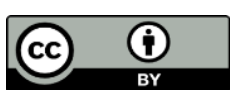

Este artigo está licenciado sob forma de uma licença Creative Commons Atribuição 4.0 Internacional, que permite uso irrestrito, distribuição e reprodução em qualquer meio, desde que a publicação original seja corretamente citada. 


\section{English literature in Brazil}

The past two decades have seen the return of discussions about literature being used in the teaching of English as a Foreign Language (EFL). It was adopted primarily in the Grammar-Translation Method, where students translated works of literature from one language to another, and then disregarded in the Audiolingual and Direct Methods. Currently, literature has been slowly regaining its status as a powerful language-learning tool, inside the scope of the still widespread Communicative Approach, and in methods that take communication and social linguistic practices into consideration.

Although canonic literary texts were used in the Grammar-Translation Method, according to Kheladi (2017), "little interest was focused on the literary dimensions of text. In other words, the aesthetic aspect of the literature was not a major concern as students were not encouraged to interact with the literary text as a work of art" (p. 11). Students should use the literary texts to learn the foreign language grammar, syntax and vocabulary, not to promote critical thinking or reflection of any kind. On the other hand, the Communicative Approach understands literature not merely as a special kind of language, but as a possibility for students to learn more about culture, social relationships and art. Literature also allows the students to identify with characters, their struggles and successes, and it enables readers to get to know themselves better.

In Brazil, English literature courses are only compulsory in higher education, in English Language majors. During classes, students have contact with poems, short stories, novels, and plays from different English-speaking countries, such as Canada, Australia, South Africa, Jamaica, United Kingdom, and the United States. At Universidade Federal de Goiás, in Goiânia, where this research was carried out, English Language Teaching (ELT) students take four semesters of literature classes. In those courses, they study short stories, poems, novels, and plays.

During classes, professors face many difficulties, such as students' lack of motivation and poor knowledge of English, the belief that literary texts are hermetic to 
the uninitiated, and time is short to go through English literature basics. These problems directly interfere with the students' ability to interpret and, therefore, enjoy literary works. These issues are mentioned in Melo Júnior's paper about teaching literature to undergraduate students in Brazil (2015) and Neuda Lago's research on undergraduate students' level of motivation in literature classes (2016).

This paper aims to discuss how English teachers work with literature in the classroom: do they adopt it in their classes? If so, how do they do it, and how do they justify its presence or absence considering their own experiences during their undergraduate years? In order to do so, this paper is based on the works of Melo Júnior (2015), Lago (2016; 2017), Babaeel and Yahya (2014), Lazar (1993), Collie and Slater (1987), and Bloemert et al. (2019).

This text is divided into different sections: the first one, the theoretical framework of the study, discusses the importance of literature and its benefits in EFL classes. The second, methodology, explains how a questionnaire, a semi-structured interview and a narrative were used to collect empirical material from the English teachers. The third, analysis, presents some parts of the data and analyzes it according to the works discussed in the first section. This research is a qualitative case study, and it contributes to understanding how former ELT students relate to English literature and how it is (or is not) a part of their practice, contributing to the EFL field.

\section{The benefits of teaching English literature in EFL lessons}

The Brazilian Official National Curricular Guidelines for English Language Courses (Diretrizes Curriculares Nacionais dos cursos de Filosofia, História, Geografia, Serviço Social, Comunicação Social, Ciências Sociais, Letras, Biblioteconomia, Arquivologia e Museologia) established by Parecer CNE / CES 492/2001, defines that professionals in this area should deal critically with verbal and non-verbal languages, in addition to being interculturally competent. According to the Guidelines, "the ELT professional must have mastery over the use of the language or languages that are the 
object of their studies, in terms of their structure, functioning and cultural manifestations" (BRASIL, 2001, p. 30) ${ }^{1}$, both in the field of linguistics and literary studies. Thus, undergraduate students must have theoretical perspectives addressed in both areas.

According to Melo Jr. (2015), in ELT courses related to English teachers' training, what usually happens is that the English language literatures and their professors face a series of challenges. These hardships go from indifferent students to pedagogical projects that limit literary studies to two subjects with a workload of either 30 or 60 hours. The first challenge mentioned above is supported by the discourse that "after becoming an English teacher, if the undergraduate student does not teach a specific class of literature in English, this kind of literature is not as important as the literature in the mother tongue"2 (MELO JR., 2015, p. 154). The second one is a reality of courses that offer double degrees in English and Portuguese. They ultimately emphasize teaching the mother tongue and its literature, relegating the foreign language to a secondary role.

Another problem often related to the teaching of literatures in English is that certain students have limited knowledge of the foreign language, which prevents them from working with the original text. Melo Jr. (2015) briefly mentions institutions in which the teaching of literatures in English is done with texts translated into Portuguese or by using so-called "graded-readers", books adapted by several publishers for English learners' fluency levels, ranging from beginner to advanced readership. On the other hand, Lago (2016) believes that limited knowledge of a language does not necessarily prevent students from studying the original, but it may undermine their understanding and interpretation of the literary work, discouraging learners.

Regardless, the importance of English-language literature in the curricula of Letters courses related to training English teachers in Brazil cannot be denied, since foreign-language literature, in this case, English literature,

\footnotetext{
${ }^{1}$ Original Portuguese passage: “o profissional em Letras deve ter domínio do uso da língua ou das línguas que sejam objeto de seus estudos, em termos de sua estrutura, funcionamento e manifestações culturais”. ${ }^{2}$ Original Portuguese passage: "se o aluno de licenciatura, ao se tornar professor de inglês, não dará aula específica de literatura em língua inglesa, ela não é tão importante quanto as literaturas em língua materna”.
} 
[...] both helps in the development of the student's own English language knowledge and enriches their inner speeches, helping them, in a process of alterity, not only to become aware and to understand (conceptualize) the reality (MEDVIÉDEV, 2012; BAKHTIN / MEDVEDEV, 1978) on the other (other countries, other cultures, etc.), but to have a better view of its own. In addition, we teach English-language literature to broaden the scope of research and teaching of this teacher (MELO JR., 2015, p. 155).

In higher education or not, the presence of literature in EFL classrooms is stimulated and valued by studies conducted worldwide. In a research conducted in the Netherlands in 2019, Bloemert et al. investigated secondary students' perspectives on the benefits of literature in an EFL classroom. According to them, a "majority of the students $(74 \%, \mathrm{n}=472)$ felt that the benefits of EFL literature lessons were language approach elements, especially 'English vocabulary and idioms' $(44 \%, \mathrm{n}=279)$ and 'English language skills' (26\%, $\mathrm{n}=163$ )" (BLOEMERT et al., 2019, p. 378). The authors point out that these were not the only benefits contemplated by students. Culture and different ways of thinking were also involved:

Over half of the students $(56 \%, \mathrm{n}=355)$ mentioned context approach elements; the most frequent element mentioned in this approach was the 'Historical, cultural, and social context' element, mentioned by $47 \%(\mathrm{n}=298)$ of all students. A third of the students mentioned reader approach elements; the most frequent element mentioned was 'Critical thinking skills and personal development', mentioned by $28 \%(n=178)$ as a beneficial element in their EFL literature classes (BLOEMERT et al., 2019, p. 378).

Babaeel and Yahya (2014) highlight, as well as Brumfit and Carter (1986), Lazar (1993), and Collie and Slater (1987) do, that literature can be used for the development of reading, writing, listening and speaking competencies by focusing on aspects such as grammar, vocabulary and pronunciation. Literary texts are authentic materials that provide a linguistic and cultural enhancement in different genres and discursive styles. Babaeel and Yahya conclude that:

[1]iterature can help the students enhance their perception of other cultures and societies. Also, literary texts can consider authentic subjects like love and war that one may experience in the real world. Indeed, literature is representational instead of referential. While referential language tends to communicate at only one level and is informational, representational language of literature considers the students and involves their feelings and perceptions 
of the real world. Literary texts help the students to activate their imagination and develop their emotions (BABAEEL; YAHYA, 2014, p. 84).

Literature can also inspire and encourage foreign language students. Shirzadi and Moheimany (2018) researched how short stories motivated 100 intermediate level students in Iran and how it affected their attitude towards reading literature in English. In their paper, Shirzadi and Moheimany conclude that "the statistical analysis revealed that employing short stories surely had significant effects on the improvement of learning motivation Iranian EFL learners" (2018, p. 82). The students who participated in the study changed their attitude towards learning a second language positively. This change was recognized using questionnaires before the work with short stories and questionnaires afterwards.

In many countries, literature in EFL classes is already a part of universities and secondary schools' curricula. For example, Zhen (2012) explains that China became more receptive to literature in EFL classes after an educational reform. The author says that "nowadays every university has literature curriculum, and every student has the chance to experience and appreciate English literature in their learning of English at college" (ZHEN, 2012, p. 36). Even though not all of these courses are well structured, the author admits that the area has made progress. Using technology such as slides, videos and songs, students can "experience literature intuitively, visually and acoustically" (ZHEN, 2012, p. 42). The author even suggests some strategies to enhance students' interest and literary appeal.

Lago (2016; 2017) points out that, in Brazil, English literatures as an academic subject on their own only exist in higher education courses. Being a professor of English literature herself, the author defends literature not only as a way of putting students in contact with other cultures, societies and their feelings but also as a tool to help students build their own identity in a foreign language. After all, in her opinion, quoting Revuz (2001), "the foreign language self is never similar, entirely, to the mother tongue self" (apud LAGO, 2016, p. 659). More than dealing with alterity and enriching inner discourses, foreign literature helps the students create and understand this new self, shaped under the viewpoint of otherness' appropriation. 
Lago (2016), as well as Melo Jr. (2015), mentions some of the difficulties regarding the teaching of literature to higher education students in Letters courses in Brazil. She interviewed her students and collected data regarding their problems in dealing with literature in a foreign language as well as their positive impressions towards this kind of work. Indeed, language limitation was a complication to some of her students, as Melo Jr. (2015) pointed out. Other problems involved situations where the students did not understand the text or thought they did not understand it, which led to a lack of classroom interaction and their belief that literature is not meant for everyone, making it inaccessible. A lack of intrinsic or extrinsic motivation was also perceived: some students did not want to study literature and only did so because it was a part of the compulsory subjects.

Lago (2016) remarks on the effects of the lack of previous knowledge about authors, genres, themes and related areas on her students. It discouraged them because they felt they needed prior or innate competence to deal with the literary text. Students sometimes felt inferior to their classmates because of this. The author also mentions how metaphors and other linguistic devices can make the text seem more incomprehensible to the students and how to demystify these feelings through cooperative learning (LAGO, 2017). On the other hand, the benefits of teaching literature are similar to the ones mentioned above: the use of authentic texts and authentic English, the expansion of students' holistic knowledge, language knowledge and cognitive skills.

Taking these benefits into consideration, this research presented a questionnaire and an interview for its participants in order to understand their experience. It aimed at investigating whether the four teachers recognized these benefits during their education or if they felt similar difficulties as the ones mentioned by Lago (2016) during their study of literature. The research also wanted to determine if the teachers worked with literature inside their classrooms, having these benefits in mind or did not do that because of their own difficulties.

\section{The case study}


This qualitative case study aims to learn more about some English teachers' relationship with English literatures during their pre-service college years, if they work with literary texts now that they have already achieved their degree, and, if so, how. Lago (2016) also interviewed undergraduate students regarding their relationship with literature. This essay, following in Lago's footsteps, aims to collect data regarding this relationship. Deviating from her work, however, the study participants are English graduates from a teacher training course.

Being qualitative in nature, this study is "a situated activity that locates the observer in the world. It consists of a set of interpretive, material practices that make the world visible" (DENZIN; LINCOLN, 2005, p. 3) in contrast to quantitative research, that is worried about the collection of number-driven empirical material. The technical instruments in qualitative research may involve "field notes, interviews, conversations, photographs, recordings and, memos to the self" (DENZIN; LINCOLN, 2005, p. 3). In this study, the instruments used were a questionnaire, a semi-structured interview and a narrative.

The questionnaire obtained personal and professional data regarding the year the teachers graduated, their workplace, the groups they teach, and their continued studies in graduate school. The semi-structured interview aimed to understand the teachers' experience with literature during their undergraduate years, giving them room to express their beliefs and personal experiences. During the study's narrative section, the participants were prompted to write about their experiences with literature and any moments they considered remarkable in their career. As Lago (2016) mentions, "the use of evidence from different types of data sources provided the data triangulation that strengthened the research" (p. 662).

This work is also a case study, "the strategy chosen when contemporary events are being examined, but one cannot manipulate the relevant behaviours" (YIN, 2001, p. 27) 3 related to these events. The techniques used in a case study involve "a wide variety

\footnotetext{
3 Original Portuguese passage: "a estratégia escolhida ao se examinarem acontecimentos contemporâneos, mas quando não se podem manipular comportamentos relevantes”.
} 
of evidence - documents, artifacts, interviews and observations" (p. 27) ${ }^{4}$. It is the study of a single entity such as a program, an institution, a person or a group of people. According to Stake (2005), a case study can be simple or complex, but it is always a "process of inquiry about the case" and "the product of that inquiry". Lüdke and André (1986) argue that the case study's interest emphasizes what is unique even if certain similarities with other cases or situations appear later during the research. This paper considers the group of English teachers who work or do not work with literature after graduation as the entity that requires analysis.

This article also takes an interdisciplinary approach, connecting the areas of foreign language learning, teaching, and foreign language literatures. It focuses on Brazilian teachers of English who work in public and language schools. Rhoten et al. (2009) define interdisciplinarity as "both a process and a practice by which a set of purposive arrangements and a sense of community are established and ultimately integrates ideas with others to form an end product" (p. 87). Furthermore, interdisciplinary studies can be defined as "a process of answering a question, solving a problem, or addressing a topic too broad or complex to be dealt with adequately by a single subject or profession" (KLEIN; NEWELL, 1997, p. 393). The study of literature itself is interdisciplinary because literature involves politics, economy, history, culture and many other known subjects.

\section{Discussion}

\section{The participants of the study}

\footnotetext{
4 Original Portuguese passage: "uma ampla variedade de evidências - documentos, artefatos, entrevistas e observações".
} 
This study had four participants, three of them female and one male. There is some snapshot on their biodata in the following paragraphs, using pseudonyms to protect their privacy.

Bibi is a 30-year-old English teacher with majors in English and Portuguese (UEG) and a master's degree in Letters and Linguistics (UFG). She has been a teacher since 2006 and currently works at a federal public high school. She is also a doctorate student at the UFG.

Maria is a 31-year-old English teacher at the UFG's Centro de Línguas. She has a major in English (UFG) and a master's degree in Music (UFG). Maria has been teaching English for four years.

Mila is a 37-year-old English teacher who also works at Centro de Línguas. She also has majors in English and Portuguese (UFG) and, during the time of the research, was doing a specialization course. Mila has been an English teacher for 19 years.

Ricky is a 25-year-old English teacher with a major in English and Portuguese (UEG) and a master's degree in Letters and Linguistics (UFG). He is also a doctorate student at UFG and has been an English teacher for eight years. Ricky works both at a federal public high school institution and a language school.

\section{Literature during the undergraduate course}

The participants were questioned about the literature courses they studied during their years as undergraduate students: how many subjects they had, and what they were called. Bibi, Mila and Ricky had two literature subjects during their undergraduate course, because it was an annual course and not a semesterly one like Maria's. Mila, Bibi and Ricky mainly studied "American literature" and "British literature". Maria had four literature subjects, and each of them lasted for a semester. They were called "Literatures in the English language I, II, III and IV". She also took a non-compulsory subject called "Children and Teen's literature in English". 
In Maria's case, because hers was not a double major degree and a semesterly course instead of an annual one, she had more chances of working with literature from different English-speaking countries, not just American or British. This opportunity was significant, as the syllabus focuses not only on the most famous and renowned authors, but also encompasses texts from countries and people who are often ignored or erased. One may name black, indigenous and women authors, and writings from Africa, Canada, India and Australia. Even the subjects' name indicates a paradigm change: they are literatures in English, not English literature or American literature.

When asked about their experiences with literature during their undergraduate years, all teachers said they had a good time in class, either because of the teacher they had or the subject and the texts themselves. Maria, in her questionnaire, said:

As a student, I have had very good experiences with literature in English, since, through the subjects of this area, I was able to get to know various literary works. In addition, through the reading and discussion of such works, I learned more about cultural aspects related to language, vocabulary, etc. ${ }^{5}$

Here, Maria points out some of the benefits of studying literature, such as learning vocabulary and cultural aspects. These were also commented by students in Lago's research (2016). This teacher participant also mentioned, in her interview, that she regards the study of literary classics as very important for her career:

I think it was nice to read some classics in English literature, because how am I going to be an English teacher without having read? I don't know, we read Frankenstein, Dracula, right, so I think it was very nice reading these as something that we had to do because it was part of the subject ${ }^{6}$.

During her interview, Maria also mentioned some of the difficulties regarding the reading of literary texts. She states that "these subjects demand a lot when we are in an

\footnotetext{
${ }^{5}$ Original Portuguese passage: "Já como estudante, tive experiências bastante profícuas com a literatura de língua inglesa, uma vez que, por meio das disciplinas da área, tive a oportunidade de conhecer diversas obras literárias. Além disso, por meio da leitura e discussão de tais obras, foi possível aprender mais sobre aspectos culturais relacionados à língua, vocabulário etc".

${ }^{6}$ Original Portuguese passage: "Eu acho que foi bacana a leitura de alguns clássicos assim da literatura de língua inglesa, que acaba que, poxa, como é que eu vou ser professor de língua inglesa sem ter lido, sei lá, nós lemos Frankeinstein, ahm, Dracula, né, então acho que foi muito bacana essa leitura como algo que a gente tinha que fazer mesmo, porque fazia parte da disciplina”.
} 
undergraduate course. There are several things to do, and these subjects demand not only reading but a more in-depth reading, a more critical reading, research..."7. Like Lago's students (2016), Maria appears to think of the literary text as a special kind of reading for the initiated and those who do not have previous knowledge should look for it to understand literature.

In her questionnaire, Mila wrote that she discovered herself a literature lover during her undergraduate course and found it an enriching subject. In the interview, she said that, at that time, she also discovered she could read to enjoy the texts. That was a crucial moment for her:

In fact, I learned to see literature differently in Professor Márcia Souza's classes. It was the moment when I fell in love with literature in the sense that it is not an obligation to read a book of this size, this thick, but she, through the activities she passed, from questions, directions in reading, she was opening my eyes to reading, other than a reading task for an objective such as a test. I remember the Scarlet Letter. So, I had always heard of that book, but I had no desire to read it. So, when she assigned this book to us, I thought, 'Oh, my God'. With the questions she asked, I began taking pleasure, pleasure really, in reading, so I remember that this book was a kind of a milestone ${ }^{8}$.

Mila's cognitive skills were enhanced by her literature classes. Bibi and Ricky mentioned their teachers as well. Bibi described her teacher as "wonderful" besides the fact that literature is also related to the English language. However, she mentions that teachers and students sometimes do not realize or focus on this aspect. Ricky said, "The teacher I had at the undergraduate course was very attentive and awakened in me a great desire to read the authors she presented to us" 9 . He also mentioned how the theory he

\footnotetext{
7 Original Portuguese passage: "São disciplinas que demandam muito. Quando a gente tá na graduação tem várias coisas pra fazer e essas disciplinas demandam não só leitura, mas uma leitura mais aprofundada, mais crítica, pesquisa...”.

${ }^{8}$ Original Portuguese passage: "Na verdade, eu conheci a literatura de uma outra forma nas aulas da professora Márcia. Foi o momento em que eu me apaixonei pela literatura no sentido de não é uma obrigação ler um livro deste tamanho, grosso desse jeito, mas ela, através das atividades que ela passava de perguntas, de direcionamentos na leitura, ela foi abrindo meus olhos pra leitura, diferente de uma leitura com objetivo de prova. Eu lembro do Scarlet Letter. Então, eu sempre ouvia falar daquele livro, mas eu não tinha vontade nenhuma de lê-lo. Então quando ela passou esse livro pra gente, eu pensei 'Ai, meu Deus'. Com as perguntas que ela fazia, eu fui tomando prazer, prazer mesmo, gosto, pela leitura, então eu lembro que esse livro é como se tivesse sido um marco".

${ }_{9}$ Original Portuguese passage: "A professora que tive na graduação era bastante atenciosa e despertou em mim uma grande vontade de ler os autores que ela nos apresentava”.
} 
read allowed him to discover authors who were usually not talked of because of their colour, religion or gender.

During her interview, Bibi recalled an episode during her literature class that had a remarkable impact on her:

I liked a lot when the teacher introduced that poem that I brought to you, Funeral Blues. She was moved, she said that poem was very representative of her life because when she lost her father it was that poem that gave her strength, she said ... that the poem represents a lot when people lose someone, we want the world to stop, it will not stop, it will continue. And another moment was a tale that we read that was Bernice bobs her hair and at that time I had my hair cut, so it was a bustle in the room because we have this relationship, we end up ... it's ... we have an affinity with the texts ${ }^{10}$.

According to Bibi's comment, it is possible to notice that students and readers draw on their experiences to understand literature and literary texts and devices. In this case, the whole classroom saw Bibi's haircut and the character's way of bobbing her hair, connecting both of them. This identification with literary works is also mentioned by Babaeel and Yahya (2014) and Lago (2016; 2017) regarding emotions and situations presented in literary texts. Once it is representational, literature works with human lives and characteristics, allowing the readers to understand themselves and the world better through the act of reading.

\section{Literature in their classes}

Regarding their work as teachers and if they use literature and literary texts in their classes, the participants could be classified into those who use it and the ones who use it regularly.

\footnotetext{
${ }^{10}$ Original Portuguese passage: "Gostei muito quando a professora apresentou aquele poema que eu trouxe pra vocês, Funeral Blues, ela emocionou, disse que aquele poema foi muito representativo pra vida dela, porque quando ela perdeu o pai foi esse poema que deu força pra ela, disse ... que aquilo representa muito quando a gente perde alguém, a gente quer o mundo pare, não vai parar, vai continuar ainda. E outro momento foi um conto que lemos que foi Bernice bobs her hair e foi na época que eu tinha cortado o cabelo e foi um alvoroço assim na sala, porque a gente tem essa relação, a gente acaba tendo essa afinidade com os textos".
} 
Maria and Mila said they do not use it because of their students' English level and the little time they have. Both teach beginners and find it challenging to present literary texts when they do not have enough language knowledge to understand the authentic material. In their interviews, Maria mentioned the reading of graded readers with her English II groups, and Mila said she wanted to work with adapted books someday:

First, in English I, I'm dying to work with literary books best suited for them, right, those that are more accessible for them. Still, I'm really worried about fulfilling the book's contents, fulfilling the whole schedule, so frequently I cannot fit a literary book into my English I classes. In English II I already did that, in English III as well..."

Because Mila and Maria work at Centro de Línguas - UFG, which already has a pre-defined textbook and specific content for each English level and group, the teachers felt they were not wholly free to work with literature in their classes. As Mila remarks, they must follow their calendar. There is little or no time left for extra activities. Both teachers believe it is possible to work with authentic literary texts in higher levels at Centro de Línguas, such as English VI, VII and VIII, primarily because of the students' language level, which should have improved considerably.

Working with graded readers is one of the difficulties Melo Júnior (2015) mentions literature teachers experience because of their students' lack of proficiency. In this case, Mila and Maria want to work with graded readers because their students are, in fact, beginners and probably did not have any contact with literature in English before. Besides, the students are not being prepared to be English teachers, which means they do not have concerns about literary schools, devices, and authors as the teachersto-be in Melo Júnior's case (2015).

During the interview, Maria talked about her work with the graded readers:

This semester, for the first time, I asked the reading of at least one book for my English II groups. There are four English II groups, and then I asked for ... in our textbook, we have some suggestions of reading, a chapter that talks about

\footnotetext{
${ }^{11}$ Original Portuguese passage: "Primeiro, no Inglês I, eu morro de vontade de trabalhar com os livros literários mais adaptados pra eles, né, que seja mais acessível pra eles, mas eu sou muito preocupada em cumprir o conteúdo do livro, cumprir todo o cronograma, então muitas vezes eu não consigo encaixar nas minhas turmas de Inglês I nenhum livro literário. Na turma de Inglês II eu já consegui, na turma de Inglês III eu já consegui...”.
} 
reading in levels, according to levels, according to the student's level and such. It has a selection of books there, and it brings a small synopsis of three books, and then I told them 'look, people, let's work with reading these books, it's very simple, it's within your vocabulary, it's within the structures that you already know and everything, and I think it's important for us to work with reading ${ }^{\prime 2}$.

It seems that Maria's goal, in this case, was not literature itself, because the graded readers suggested by the book were not adaptions of literary works, but small stories created for English learners. They belong to an Oxford graded reader series and work with reading and vocabulary skills, but not literary devices or interpretation of literary metaphors and figures.

Bibi and Ricky said that they work with different kinds of literary texts in their classrooms, and they try to use literature in class as often as they can. Bibi cited poems, short stories, fables and children's literature as genres she uses with her students. She mentioned authors such as Rupi Kaur, Robert Frost, Katherena Vermette, O. Henry and Kate Chopin. Bibi said that was a practice other English teachers at her school already had: reading authentic material with the students. At first, she was sceptical because she did not think her students would understand the text, but the reading proved to work out well. In her narrative, she wrote:

I remember that, at the time, I was intrigued because I did not believe that the students were able to read poems in English since their first formal contact with the language would take place there, in the sixth year. I remember that we chose some poems from Shel Silverstein's book Where the Sidewalk Ends and I was amazed to realize that the students, using the dictionary and with the help of their classmates, were able to read and have a lot of fun with the poems. This fact has shown me that we often deprive our students of contact with literary texts because we believe that they are not able to read such texts, that they are difficult and so on, and my practice as a teacher has shown quite the opposite. I often tell interns that I receive there and the teachers in formation that this distinction between language and literature may be common among teachers, Still, it is not for the students, because for them, literature is also a language ${ }^{13}$.

\footnotetext{
${ }^{12}$ Original Portuguese passage: "Nesse semestre, pela primeira vez, eu pedi a leitura de pelo menos um livro pras minhas turmas de Inglês II, são quatro turmas de Inglês II, e aí eu pedi pra que ... a gente tem lá no nosso livro didático, algumas sugestões de leitura, um capítulo que fala sobre a leitura em níveis, de acordo com níveis, de acordo com o nível do aluno e tal, tem uma seleção de livros lá e ele traz uma sinopsezinha de três livros e aí eu falei pra eles 'olha, pessoal, vamos trabalhar com a leitura desses livros, é bem simples, tá dentro do vocabulário de vocês, tá dentro das estruturas que vocês já conhecem e tudo e eu acho que é importante a gente trabalhar com leitura".

${ }^{13}$ Original Portuguese passage: "Lembro que na época fiquei ressabiada, pois não acreditava que os alunos conseguiram ler poemas em inglês haja vista que o primeiro contato formal de ensino de línguas se daria ali, no sexto ano. Lembro que escolhemos uns poemas do livro Where the sidewalk ends, do Shel Silverstein
} 
By providing texts from different authors and genres, Bibi allows her students to contact different cultures and values from different sociocultural contexts. Rupi Kaur, for example, is an Indian contemporary writer who uses the Internet and social media to expose her work. On the other hand, Kate Chopin lived at the beginning of the twentieth century, when women were starting to fight for their rights. Robert Frost was a male poet from the U.S., while O. Henry was a short story writer. Once again, literature is a source of authentic material for students, giving them insights on different human emotions, societies and values, as highlighted by Babaeel and Yahya (2014), Brumfit and Carter (1986), Lazar (1993), and Collie and Slater (1987).

During her interview, Bibi explained how she chooses the texts she works with:

Well, I always look for authors first, right, authors I already have familiarity with, sometimes I find an author and I see the linguistic level, if the students, if it is easy, if the students can read it. The first thing is the linguistic level, the content, yeah, to see if it is appropriate for that group. If appropriate or sometimes the language level is a bit higher, I prepare some activity to level the students, so that they can read without so much difficulty ${ }^{14}$.

Bibi works with elementary school students, and she believes they enjoy the classes where they work with literature. She said one of her students even told her "Teacher, I never thought I'd be able to read a book in English"15. Other students wanted to start following Rupi Kaur in social media because the writer has an Instagram account and posts some of her poems there. Bibi also stimulated her students to write their own poems after reading about Rupi Kaur and some of the tragedies that happened in Brazil

e fiquei maravilhada ao perceber que os alunos, com o uso do dicionário e auxílio dos colegas, conseguiram ler e se divertir bastante com os poemas. Tal fato me mostrou que muitas vezes privamos nossos alunos do contato com textos literários por acreditarmos que eles não são capazes de ler tais textos, que são difíceis e etc, e minha prática enquanto docente mostrou totalmente o contrário. Costumo sempre dizer aos estagiários que recebo lá e para os professores em formação que essa distinção entre língua e literatura pode ser até comum entre professores mas não é para os alunos, pois para eles, literatura é também língua".

${ }_{14}$ Original Portuguese passage: "Bom, eu sempre procuro primeiro autores, né, que eu já tenho familiaridade, às vezes eu encontro um autor aí eu vejo o nível linguístico, se aquilo os alunos, se é fácil, se os alunos conseguem ler. Primeira coisa é o nível linguístico, o conteúdo, né, pra ver se é apropriado praquela sala. Sendo apropriado ou às vezes se tiver um pouco mais alto o nível linguístico, eu preparo alguma atividade para nivelar os alunos, para que eles possam conseguir ler sem tanta dificuldade".

${ }^{15}$ Original Portuguese passage: "Professora, eu nunca imaginei que eu ia conseguir ler um livro em inglês". 
in 2019. She also took some of her books in English to class, and the students wanted to touch the books and see them. As children's books, they had images and vocabulary that helped readers understand the text and the students were fascinated by the fact that they had been written in English.

Ricky said he prefers to work with authors that are not very well known in Brazil and sometimes do not get the recognition they deserve because of gender, race, religion or other factors. In his narrative, Ricky said:

I therefore argue that the literature produced by feminist and black women authors has been one of my greatest reasons for continuing to resist and insisting on social transformation through writing literature and literary reading.

He believes feminist and black women authors represent the majority of his students. Working with EJA ${ }^{16}$, Ricky had the opportunity to listen to women's stories about how they did not know how to read or write and how they believed they were inferior because of their race and social status. For him, writers such as Maya Angelou, Toni Morrison and Chimamanda Adichie talk about a very similar reality to those of his students, and he tried to connect these different experiences in his classes. In his interview, Ricky talked about how he chose the texts:

This choice was based on what I believe, that literature is much more than a literary school, it is a production that says a lot about who we are as human beings, who has the right to produce literature, it is from this perspective that I choose the authors I work with ${ }^{17}$.

When asked about how his students reacted during the classes, he said:

The girls at EJA loved it because, first of all, this detachment: it is believed that literature is something very far from what they experience, and they realized that it is not. That is because Maya Angelou deals with issues very close to their

\footnotetext{
${ }^{16}$ EJA, Educação de Jovens e Adultos, teaches Adults and Young Adults to read and write, besides giving them the opportunity to continue their studies after they abandoned them before or allows them to go to school for the first time in their lives, as far as they are 15 years old for elementary school studies and 18 years old for high school.

${ }^{17}$ Original Portuguese passage: "Essa escolha se pautou no que eu acredito, que a literatura é muito mais que uma escola literária, é uma produção que diz muito sobre quem nós somos como seres humanos, quem tem o direito de produzir literatura, é bem por esse viés que eu escolho as autoras que eu trabalho".
} 
reality. Most are black, most come from a lower class, right, they gave up on their studies, had to drop out of school, were silenced, so it was a literature that made sense to them. In the letter, in the poem I showed them, the subject that Maya Angelou approached in the texts were somehow close to their reality ${ }^{18}$.

\section{Results}

Concerning the participants of this study, half (50\%) work with literature in their EFL classes. All teachers (100\%) mentioned they had good experiences regarding literature during their undergraduate course, regardless of it being a double degree or not. Even the teachers who do not work with literature at the moment seemed to be interested in working with it in the future, even if that meant using graded readers with their students to accomplish the necessary reading.

Some of the issues discussed by Melo Júnior (2015) and Lago (2016; 2017) appeared during the questionnaire, interview or narrative with the four teachers. The benefits of using literature in an EFL class mentioned were: its ability to enhance cognitive skills; improve students' vocabulary and even their confidence, because they notice they can read books in English; provide contact with authors and people from different cultures who lived similar situations in life and the use of authentic material. These benefits also appeared in the study of Bloemert et al. (2019).

Some of the difficulties regarding literature were also mentioned, such as the students' language level, the need for research or more critical reading. Maria and Mila were mostly concerned with beginners' level and how they would provide graded readers for their students. Bibi mentioned the language level of the texts she chooses, emphasizing her role in selecting works her students will understand, even if it means the text is a little above their current level of English.

\footnotetext{
${ }^{18}$ Original Portuguese passage: "As meninas do EJA amaram. Porque primeiramente, esse distanciamento: acredita-se que literatura é algo muito distante do que elas vivenciam e elas perceberam que não. Até porque a Maya Angelou trata de questões muito próximas da realidade delas. A maioria é negra, a maioria vem de uma classe baixa, né, deixaram, tiveram que abandonar os estudos, foram silenciadas. Então foi uma literatura que fez sentido pra elas. O assunto que a Maya Angelou abordava, nos textos, na carta, no poema que eu levei, é, de alguma forma eram próximos da realidade delas."
} 
Time and the characteristics of the school they work in were also mentioned by Maria and Mila as a hindrance in the process of working with literature in EFL classes. Because Centro de Línguas has a calendar and fixed dates, besides a book and several contents the teacher needs to follow, there is little time for English I or II to work with literary texts, even graded readers.

Through their answers, it was also possible to notice some of the beliefs these teachers have regarding literature. Maria and Mila seem to find it useful to work with language. In this case, literature is not literature read for itself or its aesthetics, but a language learning tool. On the other hand, Bibi and Ricky seem to see and explore literature in ways that focus not only on language but also on human problems and representations only literature seems capable of discussing, be it in a foreign or first language.

\section{Closing remarks}

The use of literature in foreign language classes has changed from taking literary texts as a translation model between languages to entirely different work. Nowadays, it is more concerned with the ability literature has to improve students' vocabulary and linguistic knowledge, provoke reflections and provide authentic material from different cultures worldwide. Literature, as mentioned by Lago $(2016$; 2017) and also Babaeel and Yahya (2014), Lazar (1993), and Collie and Slater (1987), helps students to enter into contact with different emotions, societies and representations while also exploring linguistic and literary devices important for EFL language learners.

Even though working with literature has its benefits, it also provides some difficulties to students and professors. Melo Júnior (2015) and Lago (2016; 2017) point out that, in Brazil, as literatures in English are only compulsory subjects during Letters courses, students sometimes feel unprepared to deal with literary texts. Some of them do not see the point of learning literature since they will teach the English language, and some undergraduate courses have limited time to allow a profound study of literature. 
Literature is often seen as problematic because students do not have an appropriate English level and sometimes use translated books or graded readers to understand literary works.

Focusing on four different English teachers in Goiás, and based on Lago's paper (2016), this essay explored these teachers' experiences with literature during their undergraduate courses, the use of literature in their classes, some of their reasons and beliefs regarding the use of literature in the EFL classroom. Although they do not work with literature, Mila and Maria had fruitful experiences during their undergraduate course. They would work with literature if they had more time or groups with a higher level of English.

Bibi and Ricky, who work at federal public schools, use literature in their classes, providing different genres and authors to their students. As Mila and Maria, the two of them understand the benefits provided by literature and its importance in EFL classes. Although the use of literature in their classes is not compulsory, Bibi and Ricky find literature a vital subject that helps their students connect to different people and cultures and help each other in their learning English process.

\section{References}

BABAEEL, R.; YAHYA, W. R. B. W. Significance of Literature in Foreign Language Teaching. International Education Studies, Canada, v. 7, n. 4, p. 8o-85, 2014.

BLOEMERT, J, et al. Students' perspective on the benefits of EFL literature education. The Language Learning Journal, London, v. 47, n. 3, p. 371-384, 2019.

BRASIL. Parecer CNE/CES 492/2001. BRASÍLIA: MEC, 2001.

BRUMFIT, C. J.; CARTER, R. A. Literature and language teaching. Oxford: Oxford University Press, 1986.

COLLIE, J.; SLATER, S. Literature in the language classroom: a resource book of ideas and activities. Cambridge: Cambridge University Press, 1987.

KHELADI, M. Reflections Upon The Teaching of EFL Literature as a Means for Promoting Students' Active Learning. 2017. Tese (Doutorado em Didáticas de 
Literatura e Textos Civilizatórios) - Faculdade de Letras e Línguas, Universidade de Abou Bekr Belkaïd, Chetouane, 2017.

KLEIN, J.; NEWELL, W. (1997). Advancing interdisciplinary studies. In: GAFF, J.; RATCLIFFE, J. (Eds.), Handbook of the undergraduate curriculum: A comprehensive guide to purposes, structures, practices, and changes. San Francisco: Jossey-Bass, 1997, p. 393-415.

LAGO, N. A. High education in Brazil: university students contact with English literature. Journal of Teaching and Education, v. 5, n. 1, p. 659-670, 2016. . Understanding metaphorical texts in foreign literature. Humanities and Social Sciences Review, v. 7, n. 1, p. 297-308, 2017.

LAZAR, G. Literature and language teaching: a guide for teachers and trainers. Cambridge: Cambridge University Press, 1993.

LÜDKE, M.; ANDRÉ, M. E.D.A. Pesquisa em educação: abordagens qualitativas. São Paulo: EPU, 1986.

MELO JÚNIOR, O. M. B. de. O ensino de literatura em língua inglesa no curso de Letters: uma abordagem dialógico-pragmática. Bakhtiniana Revista de Estudos do Discurso, São Paulo, v. 10, n. 1. p. 87-103, 2015.

RHOTEN, D. et al. The act of collaborative creation and the art of integrative creativity: Originality, disciplinarity and interdisciplinarity. Thesis Eleven, v. 96, n. 1, p. 83-108, 2009 .

SHIRZADI, G.; MOHEIMANY, M. Integrating literature into EFL classes: the case of bringing short stories into Iranian EFL classes to see its impact on the EFL learners' language learning motivation and their attitudes towards English literature. Language Teaching Research Quarterly, v. 5, p. 74-84, 2018.

STAKE, R. Qualitative case studies. In: DENZIN, N. K.; LINCOLN, I. S. The Sage Handbook of Qualitative Research. California: Sage Publications, 2005, p. 443-466.

ZHEN, C. Characteristics and Strategies of Literature Teaching in the EFL Context in China. International Journal of Electronics and Communication Engineering, International Research Publication House, v. 5, n. 3, p. 35-43, 2012.

YIN, R. K. Estudo de caso: planejamento e métodos. Porto Alegre: Bookman, 2001. 
CARDOSO, Anna Carolyna Ribeiro; LAGO, Neuda Alves do

Recebido em 14/o1/2021.

Aprovado em 25/06/2021.

Revista Investigações, Recife, v. 34, n. 2, p. 1 - 22, 2021 ISSN Digital 2175-294X 